УДК 619.9:636.7, DOI 10.31210/visnyk2018.04.27

(C) 2018

Радзиховський М. Л., кандидат ветеринарних наук

Житомирський національний агроекологічний університет

\title{
МАКРОСКОПІЧНІ ЗМІНИ У ЦУЦЕНЯТ ЗА ЕКСПЕРИМЕНТАЛЬНОГО ВІДТВОРЕННЯ КОРОНАВІРУСНОГО ЕНТЕРИТУ
}

\section{Рецензент - доктор ветеринарних наук, професор С. В. Гуральська}

\begin{abstract}
На основі проведеного нами аналізу літературних джерел, результатів моніторингових та власних досліджень з'ясовано, щзо вірусні ентерити займають провідне місие в інфекційній патології собак $і$ наносять значні збитки власникам тварин. Враховуючи актуальність даного питання, результатом наших досліджень є уточнення, доповнення та узагальнення даних щзодо патоморфології різних органів собак за коронавірусного ентериту, щз дасть можливість більш детально з'ясувати вплив збудника хвороби на організм тварин. У статті представлено результати вивчення макроскопічних змін у собак за експериментального відтворення коронавірусного ентериту. За результатами патолого-анатомічного розтину трупів иуценят спостерігаються мікроскопічні зміни y внутрішніх органах, а саме серозний лімфаденіт, тимусі та підилунковій залозі набряк $i$ гіперемію, нирки нерівномірно забарвлені в коричневий колір, печінка і серие збільшені, розширені судини головного i спинного мозку. Таким чином, виявлений нами комплекс патологоанатомічних змін у иуценят за експериментального відтворення хвороби можна вважати характерним критерієм патоморфологічної діагностики коронавірусного ентериту у собак.
\end{abstract}

Ключові слова: коронавірусний ентерит собак, патолого-анатомічний розтин, макроскопічні зміни, печінка, тимус, лімфатичні вузли, серие.

Постановка проблеми. Вірусні ентерити група інфекційних хвороб за яких відмічається ураження серця, печінки, нирок, кишечника тощо. Вірусні ентерити входять в п’ятірку найбільш розповсюджених хвороб собак. Найбільш розповсюдженим $\epsilon$ парвовірусний але останнім часом достатньо новий збудник починає все частіше повідомляти про себе це - коронавірус. Даний збудник є досить патогенним для молодняка i за несвоєчасної діагностики та не наданні лікарської допомоги може призводити до летального кінця $[12,15]$.

Аналіз останніх досліджень і публікацій, у яких започатковано розв'язання проблеми. В останні роки відмічається збільшення випадків захворювання собак з ознаками діареї не тільки в Україні, а й в Свропі. Під час проведення комплексу лабораторних досліджень було встанов- лено наявність не тільки парво-, а й коронавірусного ентериту. За останні шість років в Україні коронавірусний ентерит став неодмінною складовою етіологічного спектру хвороб з ураженням шлунково-кишкового тракту у собак $[7,11]$.

Коронавірус являє собою одноланцюговий РНК-вмісний вірус, який здатний інфікувати людей та значну кількість ссавців, у тому числі й собак. Філогенетична характеристика коронавірусів включає такі різновиди як альфа-, бета-, гама- та дельтакоронавірус [13]. Стосовно собак на сьогоднішній день відомий альфа-вірус, тропізм якого характеризується ураженням шлунково-кишкового тракту і нещодавно ідентифікований бета-коронавірус, який вражає респіраторну систему. У рідких випадках коронавірус проявляє пантропність. У таких випадках захворювання важко діагностуються і часто призводять до швидкої загибелі собак $[9,10,14]$.

Патоморфологічні зміни за коронавірусної інфекції собак вивчені досить поверхнево. Сучасна ситуація щодо розповсюдження захворюваності на коронавірусний ентерит собак потребує інтенсифікації наукових досліджень у напрямі удосконалення діагностики останнього [2].

Патоморфологічний розтин - всебічне вивчення загиблої або вбитої тварини $з$ метою уточнення правильності прижиттєвого діагнозу встановлення морфологічних змін в органах і причини його смерті $[1,3]$.

У доступних нам літературних джерелах інформації щодо наукових робіт з вивчення патологоанатомічних змін у разі коронавірусного ентериту собак на території України було виявлено в обмеженій кількості, тому вважаємо, що дана інформація $є$ актуальною і необхідною як для практикуючих лікарів ветеринарної медицини, так і для науковців.

Головною метою роботи було вивчення макроскопічних змін у собак за експериментального відтворення коронавірусного ентериту.

У завдання досліджень входило виявити діагностичний комплекс патологоанатомічних змін за коронавірусної інфекції у собак. 


\section{ВЕТЕРИНАРНА МЕДИЦИНА}

Матеріали і методики досліджень. Роботу виконували на факультеті ветеринарної медицини Житомирського національного агроекологічного університету (ЖНАЕУ).

Розтин тварин проводили в прозекторії кафедри анатомії і гістології факультету ветеринарної медицини ЖНАЕУ. Матеріалом дослідження слугував патологічний матеріал, відібраний під час патологоанатомічного розтину від цуценят (n = 5), після експериментального зараження і евтаназії.

Для проведення біопроби використовували 13 цуценят 45-денного віку, які були розділені на три групи: перша група (5 тварин) - заражали культуральним парвовірусом, друга (5 тварин) заражали культуральним коронавірусом і третя (3 тварини) - досліджували на виявлення спонтанного виникнення хвороби на випадок інфікування до початку експерименту. Евтаназію проводили активну, використовуючи лікарські засоби, що забезпечують швидке безболісне настання смерті відповідно до Європейської Конвенцієї iз захисту хребетних тварин, які використовуються для експериментальних та інших наукових цілей $[6,8]$.

Діагностичні дослідження на підтвердження коронавірусного ентериту проводили за допомогою експрес-тестів «VetExpert» та в приватній ветеринарній лабораторії в ПЛР.

Патологоанатомічний розтин собак різного віку, які загинули від коронавірусного ентериту, виконували методом часткової евісцерації в загальноприйнятій послідовності $[4,5]$.

Результати досліджень. Під час проведення патологоанатомічного розтину цуценят, експериментально інфікованих ізолятом коронавірусу, культивованим у гетерологічній культурі клітин, нами було встановлено, що макроскопічні зміни в усіх тварин у цілому були однаковими, хоча й мали незначні індивідуальні особливості щодо ступеню їх прояву. Під час зовнішнього огляду трупів відзначались погана вгодованість, матова, скуйовджена шерсть та сухувата шкіра, яка в ділянці анального отвору, кореня хвоста і задньої поверхні стегон була забруднена фекаліями жовтуватого кольору.

В усіх досліджених соматичних і вісцеральних лімфовузлах макроскопічні зміни були подібними. Вони мали білуватий колір, були збільшені (капсула напружена, часточкова будова виразна, на розрізі підвищеної вологості, паренхіма випиналася). Такі макроскопічні зміни характерні для серозного лімфаденіту. Тимус був в’ялий, набряклий, нерівномірно гіперемійований.

У шлунку під час проведення патологоанато- мічного розтину будь-які видимі зміни не реєструвались. Основні макроскопічні зміни локалізувалися в тонкій кишці. Ї̈і стінка була дещо гіперемійована. Кровоносні судинні брижі були розширені, переповнені кров'ю, а лімфатичні судини - розширені й переповнені лімфою. Слизова оболонка була набрякла, незначною мірою гіперемійована, вкрита густим, білим слизом, схожим на рисовий відвар. У товстій кишці будь-які макроскопічні зміни не виявлялися.

Підшлункова залоза в усіх цуценят була гіперемійована й виразно набрякла, внаслідок чого добре вирізнялась часточковість її будови.

Печінка була збільшена, нерівномірного темно-червоного кольору, з поверхні розрізу виділялася темно-червона кров. Жовчний міхур був дещо розтягнутий жовтувато-зеленою розрідженою жовчю.

Макроскопічні зміни в нирках, як і аналогічні зміни в тонкій кишці, помітно відрізнялися від таких за спонтанної і експериментальної коронавірусної інфекції. Нирки 3 поверхні мали нерівномірний коричнюватий колір. На розрізі такий же колір мала вся кіркова речовина. Мозкова речовина була нерівномірно синюшна. При цьому границя між кірковою й мозковою речовинами була досить виразна.

Селезінка в усіх досліджених нами цуценят видимих змін не мала.

Серце мало округлу форму за рахунок виразного розширення правого шлуночка, рідше - всієї правої половини органу. Серцевий м’яз був в'ялий, нерівномірно забарвлений - 3 ділянками сіруватого кольору, на яких м'язова тканина органу нагадувала ошпарене м’ясо. Кровоносні судини органу були виразно розширені, переповнені кров'ю.

Легені мали тістувату консистенцію, більшменш рівномірне рожеве забарвлення. Консистенція органу була тістоподібною (ямка в разі натискання вирівнювалась повільно або ж взагалі не вирівнювалась). Шматочки легень у воді плавали важко. 3 поверхні розрізу виділялась піниста рідина червонуватого кольору. Така ж рідина знаходилась у просвіті трахеї та в просвіті великих бронхів.

Судини головного та спинного мозку і їх оболонок були вразно розширені, переповнені кров'ю. В інших органах і тканинах матроскопічні патологоанатомічні зміни нами встановлені не були.

\section{Висновки:}

1. Основні макроскопічні зміни за коронавірусного ентериту локалізувалися в тонкій кишці, 


\section{ВЕТЕРИНАРНА МЕДИЦИНА}

а саме набряк стінки, гіперемія, розширені та переповнені кровоносні і лімфатичні судини.

2. Печінка темно-червоного кольору, збільшена, жовчний міхур наповнений жовтуватозеленою розрідженою жовчю.

3. За експериментального відтворення коронавірусного ентериту у собак реєстрували сероз-

\section{БІБЛІОГРАФІЯ}

1. Боль Б. К. Патологоанатомическое вскрытие сельскохозяйственных животных / Б. К. Боль. 3-е изд., испр. и доп. - М., 1950. - 264 с.

2. Горальський Л. П. Патоморфологічна диференційна діагностика парвовірусного та коронавірусного ентериту у собак / Л. П. Горальський, М.Л. Радзиховський, С.С. Заїка // Науковий журнал ЖНАЕУ «Наукові горизонти», 2018. - №3(66). - С. 10-14.

3. Жаров А. В. Вскрытие и патоморфологическая диагностика болезней животных / А. В. Жаров, И. В. Иванов, А. П. Стрельников. - М. : Колос, $2000 .-400 \mathrm{c}$.

4. Зон $Г$. А. Патологоанатомічний розтин тварин / Навчальний посібник / Г. А. Зон, М. В. Скрипка, Л. Б. Іванівська. - Донецьк, 2009. - 190 с.

5. Ссіна E. Значення патоморфологічних досліджень у діагностиці захворювань тварин / Е. Єсіна, М. Потоцький // Ветеринарна медицина України. - 2007. - №3. - С. 27-30.

6. Інтернет-сайт https://www.pravda.ru/society/ zoo/veterinary/22-07-2010/1041783-euthanasia-0.

7. Радзиховський М. Л. Моніторинг ентеритів вірусної етіології у собак / М. Л. Радзиховський // Наук. Вісн. ЛНУВМ та БТ ім. С. 3. Гжицького. - 2016. - №1 (65), т. 18, ч. 1. - С. 138-142.

8. Стекольников А. А., Коробов А. В. Профессиональная этика врача ветеринарной медицины. - Спб. : Лань, 2004. - 288 с.

9. Characterization of a recombinant canine

\section{ANNOTATION}

Radzykhovskyi M. L. Macroscopic changes in puppies with experimental coronaviral enteritis.

On the basis of our analysis of literary sources, the results of monitoring and our own research, it was found out that viral enteritis occupies a leading place in the infectious pathology of dogs and causes significant damage to animal owners.

Taking into account the relevance of this issue, the result of our research is specification, supplement and generalization of the data on the pathomorphology of various organs of dogs for coronaviral enteritis, which will give an opportunity to more precisely determine the effect of the ний лімфаденіт, набряк і гіперемію тимуса та підшлункової залози.

Перспективи подальших досліджень. 3 метою повного охоплення патоморфологічної картини хвороби у подальшому доцільно провести гістологічні дослідження органів і тканин за коронавірусного ентериту собак.

coronavirus with a distinct receptor-binding (S1) domain / Andrew D. Regan, Jean K. Millet, Long Ping V. Tse [et all.] // Virology. - 2012. - №430 (2). - P. 90-99.

10. Cirone Francesco The Polarity of Entry and Release of Canine Coronavirus From Epithelial Cells / Annamaria Pratelli // Biomed J Sci and Tech Res. - 2018. - №2 (1). - P. 1-2.

11. Detection of Canine Pneumovirus in Dogs with Canine Infectious Respiratory Disease / Judy A. Mitchell, Jacqueline M. Cardwell, Randall W. Renshaw et all / J Clin Microbiol. 2013 Dec; 51(12): 4112-4119.

12. Genetic diversity of a canine coronavirus detected in pups with diarrhoea in Italy / A. Pratelli, V. Martella, N. Decaro et all / J. Virol Methods. 2003;110:9-17.

13. Inhibition of RANTES expression by indirubin in influenza / N. Mak, C. Leung, X. Wei [et al.] // Biochemical Pharmacology. - 2004. P. 167-174.

14. Rottier Peter J. M. The Evolutionary Processes of Canine Coronaviruses / Peter J. M. Rottier // Advances in Virology. - 2011. - Режим доступу : https://www.ncbi.nlm.nih.gov/pmc/ articles/PMC3265307/ - Перевірено : 11.07.2018.

15. Virusnij enterit u sobak - Режим доступу : https: // http://zverivdom.com/article/virusnyjeenterity-u-sobak.

pathogen on the animal's body.

The purpose of this work was to study and characterize the pathomorphological changes in the large intestine in experimental contamination of dogs with coronavirus enteritis.

The work was carried out at the Faculty of Veterinary Medicine of Zhytomyr National Agroecological University (ZNAEU). Thanatopsy of the animals was carried out in the special laboratory of the Department of Anatomy and Histology.

The article presents the results of the study of macroscopic changes in dogs in experimental 


\section{ВЕТЕРИНАРНА МЕДИЦИНА}

reproduction of coronaviral enteritis. According to the results of the pathological anatomical section of the corpses of the puppies, microscopic changes in the internal organs are observed, namely, serous lymphadenitis, thymus and pancreas, edema and hyperemia, the kidneys are irregularly browncolored, liver, heart as well as vessels of the brain and spinal cord are enlarged.

Thus, our complex of pathoanatomical changes in puppies in the experimental reproduction of the disease has been identified by us as a characteristic criterion for the pathomorphological diagnosis of coronaviral enteritis in dogs.

In the future, in order to fully cover the pathomorphological picture of the disease, it is advisable to carry out histological examination of the organs and tissues in the dog-infected Coronaviridae.

Key words: canine coronaviridae, pathologic anatomical autopsy, macroscopic changes, liver, thymus, lymph nodes, heart. 